\title{
ELECTROCHEMISTRY OF IMMOBILIZED MICROPARTICLES AND MICRODROPLETE: ACCESS TO FUNDAMENTAL DATA OF SOLID MATERIALS AND IONS
}

\section{F. Scholz $z^{1}$}

${ }^{1}$ Universität Greifswald, Institut für Biochemie, Editor-in-Chief Journal of Solid State Electrochemistry (http://link.springer.com/journal/10008) and Editor-in-Chief ChemTexts - The Textbook Journal of Chemistry (http://link.springer.com/journal/40828)

Editor of "Monographs in Electrochemistry" (https://www.springer.com/series/7386)

Felix-Hausdorff-Straße 4, 17489 Greifswald, Germany

e-mail:fscholz@uni-greifswald.de

The idea to study the electrochemistry of immobilized microparticles has been published by this author for the first time in 1989. In the last 32 years, this approach has been shown to be very successful not only for analytical characterization of solid materials, but also applicable to extract thermodynamic and kinetic data, and even to determine the age of metal specimen. In 2000, it has been shown that the electrochemistry of immobilized microdroplets gives an elegant access to determine the Gibbs free energies of ion transfer between immiscible solvents. These measurements are performed with a standard 3-electrode potentiostate and can be used also for solvents, which cannot be used in experiments with the classical 4-electrode technique.

The electrochemistry of microparticles and microdroplets share several common features with respect to the electrode mechanisms: in both cases three-phase electrodes are realized and ion and electron transfer proceed simultaneously.

This talk reviews the activities of the speaker and his cooperation partners during the last 3 decades paying special attention to those results, which are of general interest.

Key words: Electrochemistry of solids, three-phase electrodes, ion transfer between immiscible solvents. 


\section{Electrochemistry of immobilized micropartiles}

The electrochemical analysis and characterization of solid materials has always been a great challenge; however, it remained confined to electron conductors, mainly metals; it was and still is the domain of corrosion science. The last decades have also seen tremendous advances in the insertion electrochemistry of solid materials for batteries, almost exclusively studied with compact macroscopic solid electrodes.

Among the many attempts to expand the applicability of electrochemical measurements to solids, the early work of the Russian scientist A. I. Glazunov [1] is noteworthy. He called his technique electrography. A more detailed review of the history of solid state electroanalysis is available elsewhere [2]. Then, in 1989, Scholz, Nitschke and Henrion [3] have shown that metal particles can be transferred from a piece of metal to the surface of a graphite electrode by abrasion, i.e., by rubbing the graphite electrode on the surface of the metal, and soon after, the same authors have shown together with Damaschun that also mineral particles can be mechanically immobilized on an electrode for electrochemical studies [4].

The purely analytical applications, i.e., the quantitative analysis of alloys, minerals and synthetic solid materials will not be discussed here, as it is presented in detail in [2]. Instead, attention is drawn on the possibility to determine the free energies of phase transition in case of some minerals, when the two phases can undergo reversible electrochemical reactions to the same dissolved species $[5,6]$. Studies of immobilized microparticles also allowed to understand the dependencies of formal po- tentials on structure parameters as ionic radii and ion potentials, in case of polycyanometalates $[7,8]$. Another noteworthy topic is the electrochemical study of solid solutions [9-12]. Whereas X-ray diffraction of solid solutions requires a certain degree of crystallinity, the electrochemical approach also works in case of $\mathrm{X}$-ray amorphous substances (see [10]).

A number of theoretical papers have been published in which the mechanism of electrode reactions of immobilized microparticles is treated [13-17].

The electrochemical behavior of microparticles has also been studied by in-situ combination with X-ray diffraction [18], calorimetry $[19,20]$, diffuse reflection spectroscopy [21], and AFM [22-27]. These combinations allowed distinguishing the different electrode mechanisms. The studies of the electrochemistry of microparticles led to the development of an approach for separating the Gibbs free energies of ion and electron transfer in case of reversible insertion electrochemical systems $[28,29]$.

Finally, it is noteworthy to mention that the electrochemistry of microparticles gives access to the age of metal objects, be they of gold, copper, bronze, or silver [30]. These electrochemical age determinations are of very special value because so far almost no direct methods of age determinations of metals and alloys were known.

\section{Electrochemistry of immobilized micro-droplets}

When a droplet of an immiscible solvent is immobilized on a suitable electrode, and when that droplet contains a redox active com- 
pounds, but no salt, an electron transfer between the redox probe and the electrode initiates an ion transfer between the bulk electrolyte solution and the droplet solvent. Similar to the insertion electrochemistry of microparticles, the entire electrode is a three-phase electrode. When the formal potential of the redox probe in the droplet solvent is known, simple voltammetric measurements with the immobilized microdroplets allow determining the Gibbs free energies of transfer of the ions, which are transferred between the solvents [2, 31-43]. This approach allowed to determine the Gibbs energies of ion transfer, i.e., the partition constants, of ions between water and n-octanol $[32,39]$, which is not possible when using the classical 4-electrode systems. It was possible to quantify the chiral recognition energies for ions using the solvent system water / chiral organic solvent [33, 42]. Amino acid anions, cations and also peptide ions have been studied in order to quantify the lipophilicity of these ions and their constituents [36, 38]. The new technique of using immobilized droplet electrodes considerably expanded the range of ions and of solvents for which Gibbs free energies of ion transfer are accessible.

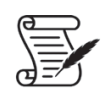

\section{Acknowledgement}

This research has been supported by Deutsche Forschungsgemeinschaft (DFG) for almost 30 years.

\section{ЕЛЕКТРОХІМІЯ ІММОБІЛІЗОВАНИХ МІКРО- ЧАСТИНОК I МІКРОКРАПЕЛЬЬ: ПІДХІД ДО ФУНДАМЕНТАЛЬНИХ ДАНИХ ТВЕРДИХ МА- ТЕРІАЛ|В ТА ІОНIB}

\section{Ф. Щольи}

Університет Грайфсвальда, Інститут біохімії, гол. редактор журналу «Електрохімія твердого тіла» (http://link.springer.com/ journal/10008) та гол. редактор журналу «Хрестоматійний підручник з хіміï» (http:// link.springer.com/journal/40828),

редактор журналу "Монограбії з електрохіміï» (https://www.springer.com/series/7386) Фелікс-Хаусдорф-штрасе 4, 17489 Грайбсвальд, Німеччина

Ідею вивчення електрохімії іммобілізованих мікрочастинок було вперше оприлюднено автором роботи в 1989 році. Отже, за останні 32 роки цей підхід показав себе дуже успішним не тільки для аналітичних характеристик твердих матеріалів, а й для застосування при отриманні термодинамічних і кінетичних даних і навіть визначення віку металевих зразків. У 2000 році було показано, що електрохімія іммобілізованих мікрокрапель дає надійний доступ для визначення вільних енергій Гіббса - переносу іонів між незмішуваними розчинниками. Ці виміри проводять із використанням стандартного триелектродного потенціостата і їх можна застосувати також для розчинників, які не можливо використовувати в експериментах із класичною чотириелектродною технікою. Електрохімія мікрочастинок і мікрокрапель має кілька спільних рис відносно електродних 
механізмів: в обох випадках реалізуються трифазні електроди і перенесення іонів та електронів відбувається водночас. У повідомленні представлено результати діяльності спікера і його партнерів зі співпраці за останні 3 десятиліття, особливу увагу приділено результатам, які становлять спільний інтерес.

Ключові слова: електрохімія твердих тіл, трифазні електроди, іонний перенос між незмішуваними розчинниками.

\section{REFERENCES}

1. Scholz F. Glazunov's electrography - the first electrochemical imaging and the first solid state electroanalysis. J Solid State Electrochem. 2021. https://doi.org/10.1007/s10008-021-04967-1

2. Scholz F., Schröder U., Gulaboski R., Doménech-Carbó A. Electrochemistry of immobilized particles and droplets, 2-nd edition, Berlin: Springer. 2015. 327.

3. Scholz F., Nitschke L., Henrion G. A. New Procedure for Fast Electrochemical Analysis of Solid Materials. Naturwissenschaften. 1989. 76:71.

4. Scholz F., Nitschke L., Henrion G., Damaschun A. A new technique to study the electrochemistry of minerals. Naturwissenschaften. 1989. 76: 167-168.

5. Lange B., Scholz F., Bautsch H-J., Damaschun F., Wappler G. Thermodynamics of the xanthoconite-proustite and pyrostilpnite-pyrargyrite transitions as determined by abrasive stripping voltammetry. Phys. Chem. Minerals. 1993. 19: 486-491.

6. Meyer B., Scholz F. Redetermination of the transformation enthalpies of the xanthoco- nite-proustite, pyrostilpnite-pyrargyrite and trechmannite-smithite phase transition. Phys. Chem. Minerals. 1997. 24: 50-52.

7. Scholz F., Dostal A. The formal potentials of the solid metal hexacyanometalates. Angew. Chem. Int. Ed. Engl. 1995. 34: 2685-2687.

8. Bárcena Soto M., Scholz F. The thermodynamics of the insertion electrochemistry of solid metal hexacyanometallates. J. Electroanal. Chem. 2002. 521: 183-189.

9. Meyer B., Zhang S., Scholz F. The quantitative analysis of mixed crystals $\mathrm{CuS}_{\mathrm{x}} \mathrm{Se}_{1-\mathrm{x}}$ with abrasive stripping voltammetry and a redetermination of the solubility product of $\mathrm{CuSe}$ and the standard potential of the $\mathrm{Cu} / \mathrm{CuSe}$ electrode. Fresenius'J. Anal. Chem. 1996. 356: 267-270.

10. Reddy S-J., Dostal A., Scholz F. Solid state electrochemical studies of mixed nickeliron hexacyanoferrates with the help of abrasive stripping voltammetry. J. Electroanal. Chem. 1996. 403: 209-212.

11. Schwudke D., Stößer R., Scholz F. Solid-state electrochemical, X-ray and spectro-scopic characterization of substitutional solid solutions of iron-copper hexacyano-ferrates. Electrochem. Commun. 2000. 2: 301-306.

12. Widmann A., Kahlert H., Petrovic-Prelevic I., Wulff $H$, Yakhmi J. V., Bagkar N., Scholz F. The structure, insertion electrochemistry and magnetic properties of a new type of substitutional solid solutions of copper, nickel and iron hexacyanoferrates/ hexacyanocobaltates. Inorg.Chem. 2002. 42: 5706-5715.

13. Lovrić M., Scholz F. A model for the propagation of a redox reaction through microcrystals. J. Solid State Electrochem. 1997. 1: 108-113.

14. Scholz F., Lovrić M., Stojek Z. The role of redox mixed phases $\{\operatorname{oxx}(\mathrm{Cnred}) 1-\mathrm{x}\}$ in so- 
lid state electrochemical reactions and the effect of miscibility gaps in voltammetry. J. Solid State Electrochem. 1997. 1: 134-142.

15. Lovrić M., Scholz F. A model for the coupled transport of ions and electrons in redox conductive microcrystals. J. Solid State Electrochem. 1999. 3: 172-175.

16. Lovrić M., Hermes M., Scholz F. Solid state electrochemical reactions in systems with miscibility gaps. J. Solid State Electrochem. 2000. 4: 394-401.

17. Schröder U., Oldham K. B., Myland J. C., Mahon P. J., Scholz F. Modelling of solid-state voltammetry of immobilized microcrystals assuming an initiation of the electrochemical reaction at a three-phase junction. J. Solid State Electrochem. 2000. 4: 314-324.

18. Meyer B., Ziemer B., Scholz F. In situ X-ray diffraction study of the electrochemical reduction of tetragonal lead oxide and orthorhombic $\mathrm{Pb}(\mathrm{OH}) \mathrm{Cl}$ mechanically immobilized on a graphite electrode. J. Electroanal. Chem. 1995. 392: 79-83.

19. Bárcena Soto M., Kubsch G., Scholz F. Cyclic voltammetry of immobilized microparticles with in situ calorimetry, Part I: The thermistor electrode. J. Electroanal. Chem. 2002. 528: 18-26.

20. Bárcena Soto M., Scholz F. Cyclic voltammetry of immobilized microparticles with in situ calorimetry, Part II: Application of a thermistor electrode for in situ calorimetric studies of the electrochemistry of solid metal hexacyanoferrates. J. Electroanal. Chem. 2002. 528: 27-32.

21. Schröder U., Scholz F. Microscopic in situ diffuse reflectance spectro electrochemistry of solid state electrochemical reactions of particles immobilized on electrodes. J. Solid State Electrochem. 1997. 1: 62-67.

22. Hasse U., Scholz F. In situ atomic force microscopy of the reduction of lead oxide nanocrystals immobilized on an electrode surface. Electrochem. Commun. 2001. 3: 429-434.

23. Hasse U., Nießen J., Scholz F. Atomic force microscopy of the electrochemical reductive dissolution of sub-micrometersized crystals of goethite immobilized on a gold electrode. J. Electroanal. Chem. 2003. 556: 13-22.

24. Hasse U., Wagner K., Scholz F. Nucleation at three-phase junction lines: In situ atomic force microscopy of the electrochemical reduction of sub-micrometer size silver and mercury (I) halide crystals immobilized on gold electrodes. J. Solid State Electrochem. 2004. 8: 842-853.

25. Hasse U., Scholz F. In situ AFM observation of the electrochemical reduction of a single silver sulphide crystal and the recrystallization of the resulting silver crystal. Electrochem.Commun. 2005. 7: 173-176.

26. Hasse U., Scholz F. Atomic force microscopic study of the chemical oxidation of silver crystals immobilized on platinum and on quartz. Electrochem. Commun. 2006. 8: 1005-1010.

27. Hasse U., Scholz F. In situ AFM evidence of the involvement of an oversaturated solution in the course of oxidation of silver nanocrystals to silver iodide crystals. Electrochem. Commun. 2004. 6: 409-412.

28. Cisternas R., Kahlert H., Wulff H., Scholz F. The electrode responses of a tungsten bronze electrode differ in potentiometry and voltammetry and give access to the individual contributions of electron and proton transfer. Electrochem. Commun. 2015. 56: 34-37.

29. Scholz F., Doménech-Carbó A. The thermodynamics of insertion electrochemical electrodes - a team play of electrons and ions 
across two separate interfaces (minireview). Angew. Chem. Int. Ed. 2019. 19: 3279-3284.

30. Doménech-Carbó A., Scholz F. Electrochemical age determinations of metallic specimens - utilization of the corrosion clock.Acc. Chem. Res. 2019. 52:400-406.

31. Scholz F., Komorsky-Lovrić Š., Lovrić M. A new access to Gibbs free energies of transfer of ions across liquid-liquid interfaces and a new method to study electrochemical processes at well-defined three-phase junctions. Electrochem. Commun. 2000. 2: 112-118.

32. Gulaboski R., Mirčeski V., Scholz F. An electrochemical method for the determination of the standard Gibbs energy of anion transfer between water and n-octanol. Electrochem. Commun. 2002. 4: 277-283.

33. Scholz F., Gulaboski R., Mirčeski V., Langer P. Quantification of the chiral recognition in electrochemically driven ion transfer across the interface water|chiral liquid. Electrochem. Commun. 2002. 4: 659-662.

34. Mirčeski V., Gulaboski R., Scholz F. Determination of the standard Gibbs energies of transfer of cations across the nitrobenzene/ water interface utilizing the reduction of iodine in an immobilized nitrobenzene droplet. Electrochem. Commun. 2002. 4: 814-818.

35. Komorsky-Lovrić Š., Riedl K., Gulaboski R, Mirčeski V., Scholz F. Determination of standard Gibbs energies of transfer of organic anions across the water | nitrobenzene interface. Langmuir. 2002. 18: 8000-8005; Correction: 2003. 19: 3090.

36. Gulaboski R., Mirčeski V., Scholz F. Determination of the standard Gibbs energies of transfer of cations and anions of amino acids and small peptides across the water | nitrobenzene interface. Amino Acids. 2003. 24: 149-154.
37. Gulaboski R., Riedl K., Scholz F. Standard Gibbs energies of transfer of halogenate and pseudohalogenate ions, halogen substituted acetates, and cycloalkylcarboxylate anions at the water| nitrobenzene interface. Phys. Chem. Chem. Phys. 2003. 5: 1284-1289.

38. Gulaboski R., Scholz F. The lipophilicity of peptide anions - an experimental data set for lipophilicity calculations. J. Phys. Chem. B. 2003. 107: 5650-5657.

39. Bouchard G., Galland A., Carrupt P-A., Gulaboski R., Mirčeski V., Scholz F., Girault H. H. Standard partition coefficients of anionic drugs in the n-octanol/water system determined by voltammetry at three-phase electrodes. Phys. Chem. Chem. Phys. 2003. 5:3748-3751.

40. Scholz F., Gulaboski R., Caban K. The determination of standard Gibbs energies of transfer of cations across the nitrobenzene | water interface with the help of a threephase electrode. Electrochem. Commun. 2003. 5: 929-934.

41. Gulaboski R., Caban K., Stojek Z., Scholz F.The determination of the standard Gibbs energies of ion transfer between water and heavy water by using the three-phase electrode approach. Electrochem. Commun. 2004. 6: 215-218.

42. Scholz F., Gulaboski R. Gibbs energies of transfer of chiral anions across the interface water|chiral organic solvent determined with the help of three-phase electrodes. Faraday Discussions. 2005. 129: 169-177.

43. Scholz F., Gulaboski R. Determination of Gibbs energies of ion transfer across water/ organic liquid interfaces with three-phase electrodes. Chem. Phys. Chem. 2005. 6: 1628.

Стаття надійшла 20. 09. 2021. 